\title{
Tumour necrosis factor blockade did not prevent the increase of muscular muscle RING finger-1 and muscle atrophy F-box in arthritic rats
}

\author{
M Granado, A I Martín, T Priego, A López-Calderón and M A Villanúa \\ Department of Physiology, Faculty of Medicine, Complutense University, 28040 Madrid, Spain \\ (Requests for offprints should be addressed to M A Villanúa; Email: anvi@med.ucm.es)
}

\begin{abstract}
Chronic inflammation is associated with a decrease in body weight and cachexia, which is characterized by anorexia and skeletal muscle wasting. The expression of atrogens muscle RING finger-1 (MuRF-1) and muscle atrophy F-box (MAFbx) are increased in muscle atrophy and it is known that tumour necrosis factor (TNF) regulates skeletal muscle loss through TNF receptor p55 (TNFRI). The aim of this study was to examine the effect of polyethylene glycol linked to soluble TNFRI (PEG-sTNFRI) on gene expression of the atrogens MuRF-1 and MAFbx in skeletal muscle of arthritic rats. Rats were injected with Freund's adjuvant and, 15 days later, arthritic and control rats were injected daily with PEG-sTNFRI ( $1 \mathrm{mg} / \mathrm{kg}$, s.c.) or saline for 8 days. Arthritis
\end{abstract}

decreased body weight gain, the weight of skeletal muscle and adipose mass. PEG-sTNFRI administration increased body weight gain and adipose mass of arthritic rats; however, it did not modify the skeletal muscle weight. The gene expression of TNF- $\alpha$, MuRF1 and MAFbx, IGF-I and IGFBP-5 were increased in the skeletal muscle of arthritic rats, and the administration of PEG-sTNFRI did not modify these parameters. These data suggest that the anti-TNF agent PEG-sTNFRI did not prevent the increase in E3 ubiquitinligating enzymes, MuRF1 and MAFbx, gene expression in the skeletal muscle of arthritic rats.

Journal of Endocrinology (2006) 191, 319-326

\section{Introduction}

Adjuvant-induced arthritis is an animal model for chronic inflammation and rheumatoid arthritis characterized by a decrease in body weight and cachexia (Roubenoff et al. 1997, Ibáñez de Cáceres et al. 2000). Cachexia, which also prevails in other situations such as burns, sepsis and cancer, is characterized by anorexia and tissue wasting, reflected essentially in a loss of adipose tissue and skeletal muscle.

The skeletal muscle loss can be due to both the reduction in protein synthesis and the increase in myofibrillar protein breakdown. The increased protein breakdown seems to play a major role in muscle wasting as observed in rats with sepsis (Hasselgren et al. 1989) and in cancer patients (Tisdale 2000). Skeletal muscle contains three major proteolytic systems; one of them is the ubiquitin-proteasome-dependent pathway that mediates the degradation of the most abundant contractile proteins (Mitch \& Goldberg 1996). Ubiquitin targets specific protein substrates for degradation and this action involves the ubiquitin-activating enzyme (E1), ubiquitin-conjugating enzymes (E2), and, in general, ubiquitin-protein ligases (E3) (Hershko et al. 2000). There are two new ubiquitin ligases that seem to be specifically involved in myofibrillar protein degradation, the mouse atrophy gene-1 (atrogin-1; Gomes et al. 2001), also described as the rat muscle atrophy F-box (MAFbx; Bodine et al. 2001), and the rat muscle RING finger-1 (MuRF-1; Bodine et al. 2001). Their expression is increased in catabolic conditions that result in muscle atrophy (Bodine et al. 2001, Gomes et al. 2001, Dehoux et al. 2003). Recently, Lecker et al. (2004) has confirmed that these two atrogens are clearly essential in the process of muscle wasting. In addition, recent studies from our laboratory have provided evidence that arthritis-induced muscle cachexia mainly reflects increased ubiquitin-proteasome-dependent proteolysis and is associated with up-regulated gene expression of E3 ubiquitin-ligating enzymes MuRF-1 and MAFbx in skeletal muscle (Granado et al. 2005).

Muscle proteolysis, in particular, activation of the ubiquitin-proteasome system, has been reported to be regulated by tumour necrosis factor (TNF- $\alpha$ ) (Llovera et al. 1997) and insulin-like growth factor (IGF-I) (Chrysis \& Underwood 1999). Anti-TNF antibodies prevented increased protein breakdown and increased expression of ubiquitin in skeletal muscle from rats with hepatoma (Costelli et al. 1993, Llovera et al. 1996). Moreover, inhibition of TNF production in vivo by xanthine derivatives, such as pentoxifylline or torbafylline prevented muscle wasting and suppressed the enhanced ubiquitin-proteasome-dependent proteolysis in 
septic and cancer rats (Vary et al. 1999, Combaret et al. 2002). In arthritic rats, the increase in muscular $M u R F-1$ and $M A F b x$ gene expression was accompanied by the increase in the gene expression of TNF- $\alpha$ (Granado et al. 2005). Catabolic actions of TNF can be exerted in different ways. One possibility is that TNF- $\alpha$ acts directly on skeletal muscle to induce muscle catabolism. Alternatively, TNF- $\alpha$ can act indirectly, stimulating skeletal muscle catabolism by modifying hormones that regulate protein turnover, such as IGF-I (Fernández-Celemín et al. 2002) or by inducing anorexia (Tracey et al. 1990).

The role of IGF-I in muscle cachexia remains unclear, since this growth factor stimulates muscle protein synthesis, but it does not prevent the sepsis-induced increase in muscle protein breakdown (Fang et al. 2000). However, IGF-I has also been reported to inhibit the ubiquitin-proteasome system in skeletal muscle in a catabolic state induced by dexamethasone (Chrysis \& Underwood 1999). The actions of IGF-I are modulated locally by the IGF-binding proteins (IGFBPs). IGFBP-5 binds to the extracellular matrix and modulates the muscle's response to IGF-I (Schneider et al. 2002). A downregulation of IGFBP-5 has been reported by microarray studies in several models of muscular wasting (Lecker et al. 2004). However, in arthritic rats, we found that catabolic response in skeletal muscle was associated with increased gene expression of IGF-I and IGFBP-5 (Granado et al. 2005).

Since most of the TNF- $\alpha$ effects on skeletal muscle protein turnover are mediated through TNF receptor p55 (TNFRI) (Llovera et al. 1998), in the present study we tested the hypothesis that administration of high affinity anti-TNF agent, polyethylene glycol linked to soluble TNFRI (PEG-sTNFRI) inhibits the muscular atrophy and the increase in E3 ubiquitinligating enzymes MuRF-1 and MAFbx gene expression in skeletal muscle of arthritic rats. Since catabolic response in skeletal muscle was associated with increased gene expression of TNF- $\alpha$, IGF-I and IGFBP-5 in our previous study (Granado et al. 2005), mRNA levels for TNF- $\alpha$, IGF-I and IGFBP-5 in gastrocnemius muscle were also determined.

\section{Materials and Methods}

\section{Animals and experimental design}

Male Wistar rats were housed three or four per cage and were given a regular supply of food and water and allowed to feed ad libitum, under constant conditions of temperature $\left(20-22{ }^{\circ} \mathrm{C}\right)$ and light (lights on from 0730 to $1930 \mathrm{~h}$ ). The procedures followed the guidelines recommended by the EU for the care and use of laboratory animals. Control and arthritic rats were purchased from Charles River (Barcelona, Spain). Arthritis was induced by an intradermal injection of a suspension of $1 \mathrm{mg}$ heat-killed Mycobacterium butyricum in incomplete Freund's adjuvant. The injection was given in the plantar surface of the right hind paw under ketamine $(75 \mathrm{mg} / \mathrm{kg})+$ diazepan $(5 \mathrm{mg} / \mathrm{kg})$ anaesthesia. Control animals were injected with vehicle (paraffin oil). Fifteen days after adjuvant injection,
20 control and 24 arthritic rats were divided into two groups, one injected daily with $1 \mathrm{mg} / \mathrm{kg}$ s.c. PEG-sTNFRI (Amgen Inc, Thousand Oaks, CA, USA) and the other with $250 \mu \mathrm{l}$ saline, until day 22 after adjuvant injection. At this dose, this TNF-binding complex is able to block the systemic TNF- $\alpha$ response (evaluated by its cytotoxicity activity) as well as plasma TNF- $\alpha$ bioactivity in baboons challenged with a lethal Escherichia coli bacteraemia (Solorzano et al. 1998). Assessment of arthritis was performed by measuring the arthritis index of each animal, which was scored by grading each paw from 0 to 4. Grading was determined as the following: 0, neither erythema nor swelling; 1, slight erythema or swelling of one or more digits; 2 , swelling of entire paw; 3 , erythema and swelling of the ankle; 4, ankylosis, incapacity to bend the ankle. The severity score was the sum of the clinical scores of each limb, the maximum value being 16 (Tanaka et al. 1996). Rats having an arthritis index score below 8 on day 15 (1 out of 25 rats) were excluded from the experiment. All rats were weighed daily. Food intake per cage was calculated daily by measuring the difference between the initial and the remaining amount of pellets in the feeder, and expressed as grams per $100 \mathrm{~g}$ of body weight throughout the 8 days of treatment.

On day 22 after adjuvant or vehicle injection, all rats were killed by decapitation, $2.5 \mathrm{~h}$ after the last PEG-sTNFRI or saline injection. Gastrocnemius muscle from the left paw was frozen in liquid nitrogen and stored at $-80{ }^{\circ} \mathrm{C}$. Gastrocnemius muscle from the right paw and epididymi fat were removed, dissected and weighed.

\section{RNA extraction and real-time PCR}

Total RNA from skeletal muscle was extracted by the guanidine thiocyanate method using a commercial reagent (Ultraspec RNA, Biotecx Laboratories, Houston, TX, USA). The extracted RNA was dissolved in diethyl pyrocarbonate water with $0 \cdot 1 \%$ SDS and quantified at $260 \mathrm{~nm}$; RNA integrity was confirmed by agarose gel electrophoresis. For RT-PCR analysis, $2 \mu \mathrm{g}$ skeletal muscle mRNA were reverse transcribed in a total volume of $30 \mu \mathrm{l}$ at $37^{\circ} \mathrm{C}$ for $60 \mathrm{~h}$ with 125 units of Moloney murine leukaemia virus RT (Maxim Bioch, San Francisco, CA, USA). Each RT-PCR reaction consisted of $2.5 \mu \mathrm{l}$ cDNA, SYBR Premix Ex Taq (Takara Otsu, Shiga, Japan), and $300 \mathrm{nM}$ forward and reverse primers in a reaction volume of $25 \mu \mathrm{l}$. Reactions were carried out on a SmartCycler (Cepheid, Sunnyvale, CA, USA). Primers for PCR were obtained from previously published sequences of TNF- $\alpha$, MuRF-1 and IGF-I (Dehoux et al. 2003), r18S (Bar et al. 2003) or using the rat GenBank and the EXIQON ProbeLibrary IGFBP-5 and MAFbx. Primers were designed to span a single sequence derived from two exons (i.e. separated by an intron in genomic DNA and primary RNA transcripts to minimize amplification). Parameters included an initial activation of hotStar Taq DNA polymerase at $95^{\circ} \mathrm{C}$ for $10 \mathrm{~s}$, followed by 40 cycles of denaturation at $94{ }^{\circ} \mathrm{C}$ for $15 \mathrm{~s}$, annealing at $52{ }^{\circ} \mathrm{C}$ (MAFbx), $53{ }^{\circ} \mathrm{C}$ (MuRF-1 and IGFBP-5), $55^{\circ} \mathrm{C}$ (IGF-I), $57^{\circ} \mathrm{C}(\mathrm{TNF}-\alpha)$, and $60^{\circ} \mathrm{C}(\mathrm{r} 18 \mathrm{~S})$ 
for $30 \mathrm{~s}$, and extension at $72{ }^{\circ} \mathrm{C}$ for $30 \mathrm{~s}$. Specific amplification was confirmed by the presence of single peak in the melting curve plots. In addition, the PCR products were analysed in agarose gel electrophoresis. Results were calculated as percentage of control rats injected with saline, using the $\Delta \Delta C_{\mathrm{T}}$ method (Livak \& Schmittgen 2001) with $r 18 S$ as the control gene.

\section{Statistical analysis}

Statistics were computed using the statistics program STATGRAPHICS plus for Windows (Manugistic, Inc., Rockville, MD, USA). Data are presented as mean \pm s.E.M. and were analysed by one-way ANOVA followed by least significant difference (LSD) multiple range test or two-way ANOVA with arthritis and PEG-sTNFRI as factors. When the two-way ANOVA indicated a significant interaction between factors, individual means were compared with LSD multiple range test. Epididymi fat weight and TNF- $\alpha$ mRNA data were subjected to $\log$ transformation, since variances showed a non-normal distribution after KolmogorovSmirnov test. Statistical significance was set at $P<0 \cdot 05$.

\section{Results}

As shown in Fig. 1, arthritic rats injected with saline gained less body weight than controls rats, between days 15 and 22 after adjuvant injection $(P<0 \cdot 01)$. This decrease in body weight gain was concomitant with a significant $(P<0 \cdot 05$ and $0 \cdot 01)$ decrease in food intake (Fig. 1, upper and lower panel). PEGsTNFRI administration to arthritic rats induced an increase in body weight gain as compared with arthritic rats injected with saline $(P<0.05$ on days $1-3$ and $P<0.01$ on days $4-7)$. The stimulatory effect of PEG-sTNFRI treatment on body weight is associated with an increase in food intake, since from days 2 to 7 of the experiment, food intake was statistically increased in arthritic rats treated with PEG-sTNFRI $(P<0.05$ and 0.01$)$ as compared with arthritic rats injected with saline. The 8-day administration of PEG-sTNFRI did not modify body weight gain or food intake in control rats (Fig. 1).

Arthritis induced a marked decrease in the gastrocnemius weight and in the epididymi fat weight $(P<0 \cdot 01$; Table 1$)$. PEG-sTNFRI administration did not modify the gastrocnemius weight. However, this anti-TNF agent increased the epididymi fat $(P<0 \cdot 05$; Table 1$)$.

There was a significant increase $(P<0.05)$ in TNF- $\alpha$ mRNA in the skeletal muscle of arthritic rats injected with saline. PEG-sTNFRI administration did not modify the TNF- $\alpha$ mRNA in arthritic rats, but it increased TNF- $\alpha$ mRNA in control rats even though this increase was not statistically significant (Fig. 2).

As shown in Fig. 3, arthritis induced a significant increase in the two ubiquitin ligases MuRF-1 $(P<0 \cdot 05)$ and MAFbx $(P<0 \cdot 01)$ gene expression in the skeletal muscle. After PEG-sTNFRI administration, gene expression of MuRF-1
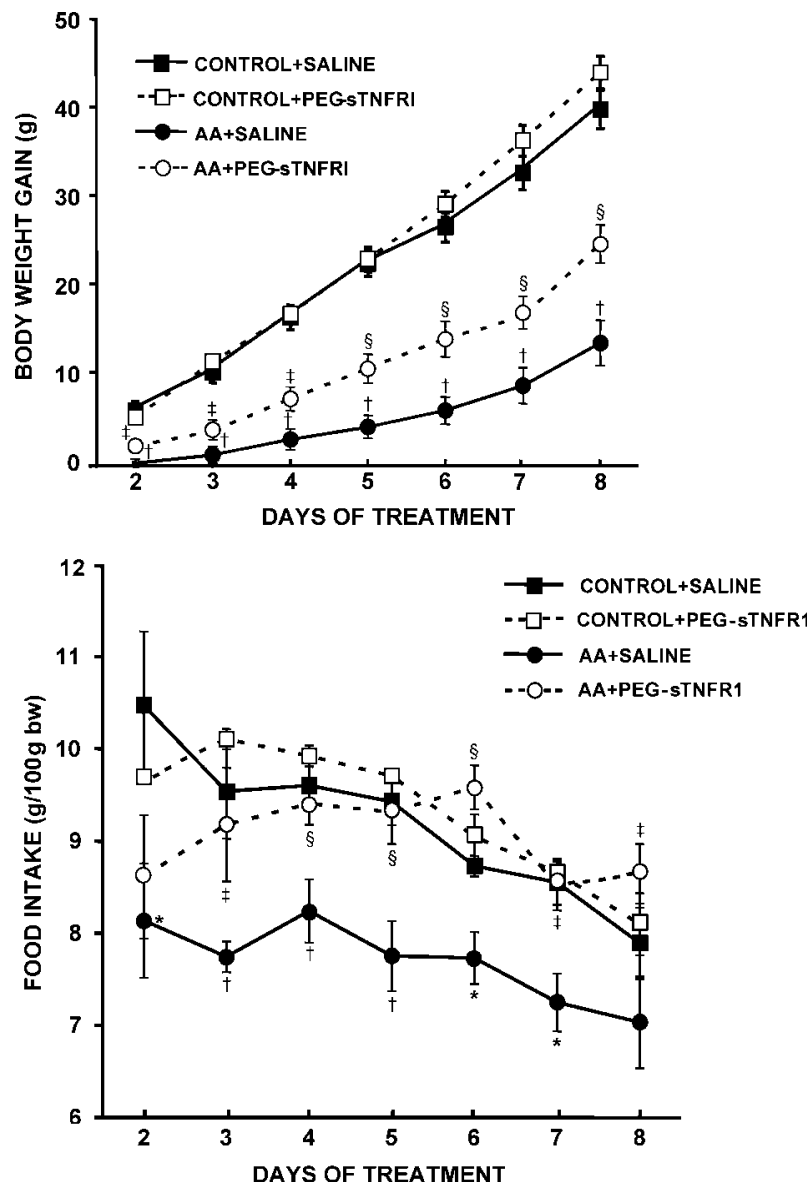

Figure 1 Effect of PEG-sTNFRI (1 mg/kg s.c.) or saline administration to control or arthritic rats (AA) on body weight gain and food intake during the 8 days of treatment (between days 15 and 22 after adjuvant injection). Values shown are mean \pm s.E.M.; $n=9-12$ rats for body weight gain and $n=3-4$ cages for food intake. $* P<0 \cdot 05$, ${ }^{+} P<0.01$ arthritis saline vs control saline, ${ }^{\ddagger} P<0 \cdot 05,{ }^{\S} P<0 \cdot 01$ arthritis PEG-sTNFRI vs arthritis saline (one-way ANOVA plus LSD multiple range test).

and MAFbx in the skeletal muscle of control and arthritic rats was similar to values found after saline administration.

The effects of arthritis and PEG-sTNFRI on IGF-I mRNA and IGFBP-5 mRNA in the skeletal muscle are shown in Fig. 4. Arthritis induced an increase in both IGF-I mRNA $(P<0 \cdot 05)$ and IGFBP-5 mRNA $(P<0 \cdot 01)$ in the skeletal muscle, whereas PEG-sTNFRI administration did not modify the mRNA of IGF-I and IGFBP-5 in both control and arthritic rats.

\section{Discussion}

Our results show that treatment with PEG-sTNFRI resulted in no change in $M u R F-1$ and $M A F b x$ gene expression in 
Table 1 Gastrocnemius and epididymi fat weight in control and arthritic (AA) rats treated with saline or PEG-sTNFRI from days 15 to 22 after adjuvant or vehicle injection

\begin{tabular}{|c|c|c|c|c|}
\hline & Control saline & Control PEG-sTNFRI & AA saline & AA PEG-sTNFRI \\
\hline Gastrocnemius (mg) & $1564 \pm 34$ & $1641 \pm 42$ & $500 \pm 26$ & $535 \pm 39$ \\
\hline Epididymi fat log (mg) & $3 \cdot 55 \pm 0 \cdot 04$ & $3 \cdot 62 \pm 0 \cdot 07$ & $3 \cdot 10 \pm 0 \cdot 03$ & $3 \cdot 22 \pm 0 \cdot 03$ \\
\hline
\end{tabular}

Two-way ANOVA revealed that there was no interaction between the effects of arthritis and PEG-sTNFRI administration on gastrocnemius weight $\left(F_{1,43}=0 \cdot 32\right.$, $P=0.57)$ and on epididymi fat $\log$ weight $\left(F_{1,21}=0 \cdot 37, P=0 \cdot 54\right)$. Arthritis decreased the gastrocnemius weight $\left(F_{1,43}=886, P<0 \cdot 01\right)$ and the epididymi fat weight $\left(F_{1,21}=100, P<0 \cdot 01\right)$. PEG-sTNFRI administration increased the epididymi fat weight $\left(F_{1,21}=5 \cdot 04, P<0 \cdot 05\right)$.

gastrocnemius muscle. These effects could be the result of the lack of effect of this anti-TNF agent on muscular $T N F-\alpha$, $I G F-I$ and $I G F B P-5$ gene expression. Moreover, data indicate that the effects on $M u R F-1$ and $M A F b x$ gene expression in gastrocnemius muscle are independent of food intake.

The weight lost by the arthritic rats is not secondary to the reduction observed in food intake (Ibáñez de Cáceres et al. 2000, Granado et al. 2006). The decrease in body weight in arthritic rats can be seen in the decrease in skeletal muscle weight and in the adipose mass. This muscular atrophy has been reported in adjuvant-arthritic rats (Hamada et al. 2000), septic rats (Cooney et al. 1999) and rats treated with TNF (Hoshino et al. 1991). In TNF-infused rats, the loss of gastrocnemius mass has been ascribed to food intake reduction (Hoshino et al. 1991). This result contrasts with that obtained in the present study, since administration of PEG-sTNFRI to arthritic rats stimulates food intake but does not alter gastrocnemius weight. These results support previous observations (Roubenoff et al. 1997) which demonstrate that although adjuvant arthritis decreases food intake, cachexia is not the result of the decrease in caloric intake. PEG-sTNFRI administration did not change gastrocnemius weight in control or in arthritic rats. Similarly, administration of

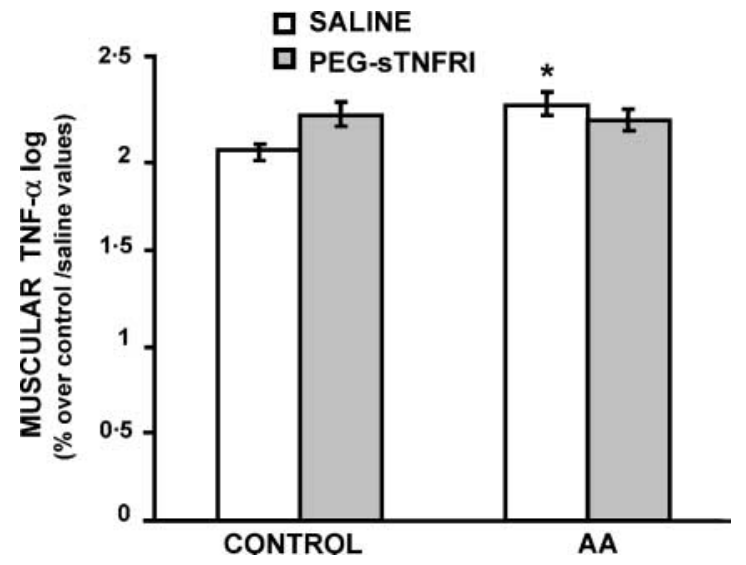

Figure 2 TNF- $\alpha$ mRNA in skeletal muscle of control and arthritic (AA) rats treated with PEG-sTNFRI (1 mg/kg s.c.) or saline. There was an interaction between the effects of arthritis and PEG-STNFRI $\left(F_{1,30}=4 \cdot 27, P<0 \cdot 05\right)$, as PEG-sTNFRI increased muscular TNF- $\alpha$ mRNA in control but not arthritic rats. Each bar represents the mean \pm S.E.M. for $8-10$ rats per group. ${ }^{*} P<0.05$ vs control saline (two-way ANOVA plus LSD multiple range test).
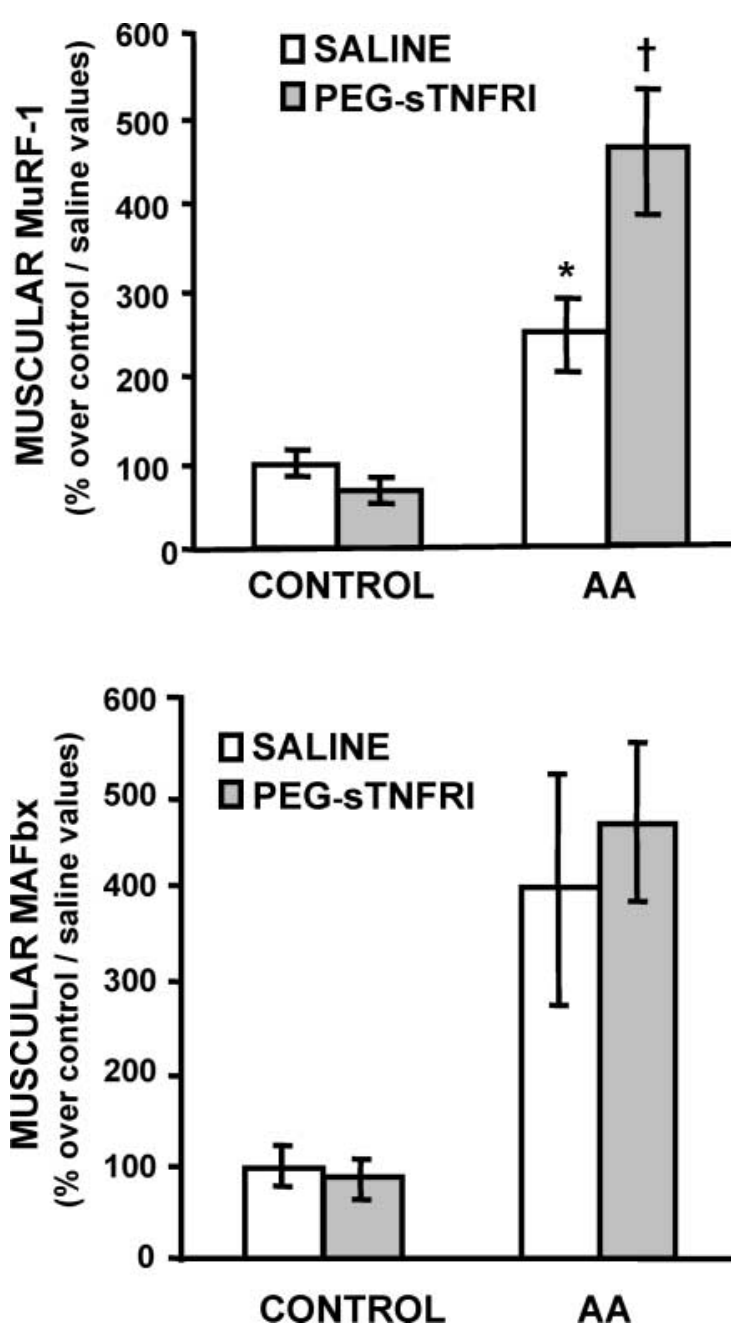

Figure 3 Effect of PEG-sTNFRI (1 mg/kg s.c.) or saline administration on skeletal muscle MuRF-1 (upper panel) and MAFbx (lower panel) gene expression in control and arthritic (AA) rats. There was an interaction between the effects of arthritis and PEG-sTNFRI on muscular MuRF-1 gene expression $\left(F_{1,33}=4.95, P<0.05\right)$, as PEG-sTNFRI increased muscular MuRF- 1 in arthritic but not in control rats. There was no interaction between the effects of arthritis and PEG-sTNFRI on muscular MAFbx gene expression $\left(F_{1,34}=0 \cdot 04\right.$, $P=0 \cdot 84)$. Arthritis increased MAFbx $\left(F_{1,34}=11 \cdot 56, P<0 \cdot 01\right)$ gene expression in the skeletal muscle. Each bar represents the mean \pm S.E.M. for $8-10$ rats per group. ${ }^{*} P<0 \cdot 05$ vs control saline, ${ }^{\dagger} P<0 \cdot 01$ vs control PEG-sTNFRI (two-way ANOVA plus LSD multiple range test). 

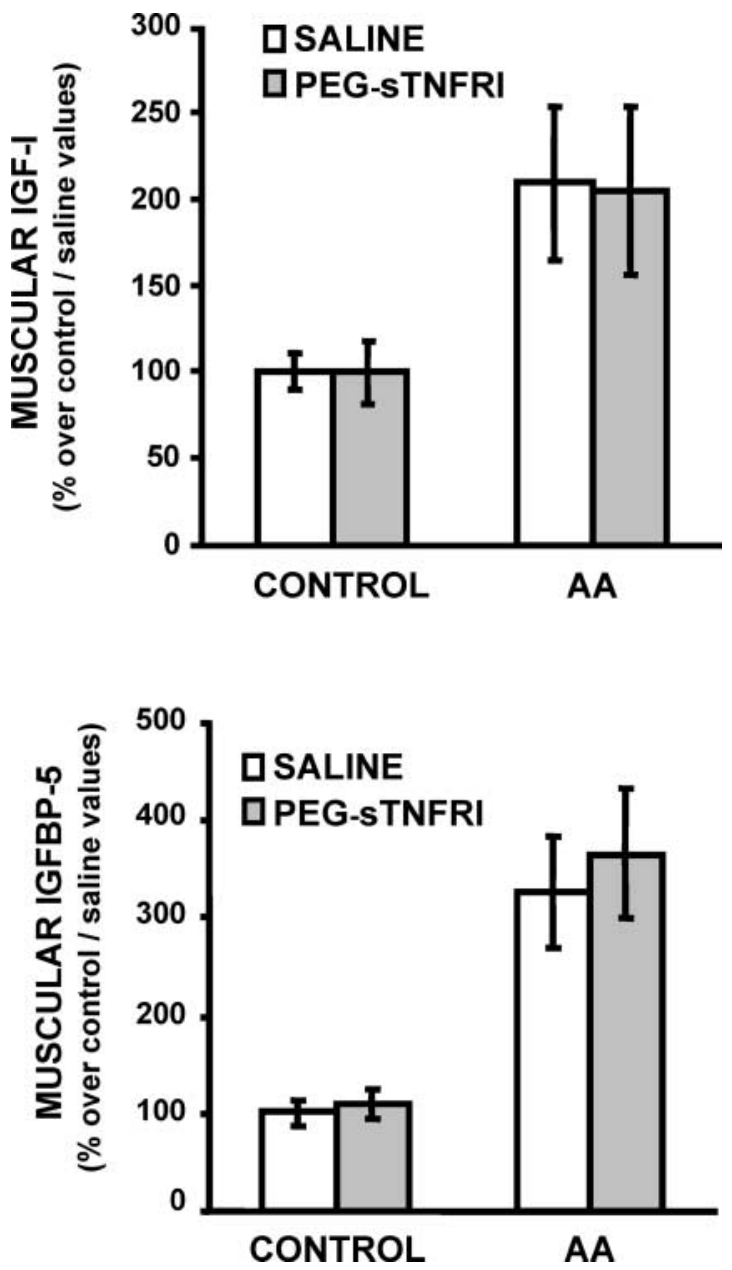

Figure 4 Skeletal muscle IGF-I mRNA (upper panel) and IGFBP-5 mRNA (lower panel) in control and arthritic (AA) rats injected with PEG-sTNFRI ( $1 \mathrm{mg} / \mathrm{kg}$ s.c.) or saline. There was no interaction between the effects of arthritis and PEG-sTNFRI on muscular IGF-I mRNA $\left(F_{1,32}=0 \cdot 00, P=0.95\right)$ and on muscular IGFBP-5 mRNA $\left(F_{1,35}=0 \cdot 06, P=0 \cdot 80\right)$. Arthritis increased IGF-I mRNA $\left(F_{1,32}=7 \cdot 02, P<0 \cdot 05\right)$ and IGFBP-5 mRNA $\left(F_{1,35}=17 \cdot 74, P<0 \cdot 01\right)$ in the skeletal muscle. Each bar represents the mean \pm s.E.M. for 9-11 rats per group (two-way ANOVA).

this TNF- $\alpha$ inhibitory protein did not modify gastrocnemius weight in control rats, although this inhibitory protein increased it in septic rats (Cooney et al. 1999). The increase in body weight gain in arthritic rats after PEG-sTNFRI administration is reflected in the increase in fat mass. There is evidence that TNF- $\alpha$ can act through the TNF- $\alpha$ receptor (TNFRI) to inhibit adipogenesis (Warne 2003).

Arthritis decreased gastrocnemius weight and increased the gene expression of ubiquitin ligases MuRF-1 and MAFbx in the skeletal muscle as previously shown (Granado et al. 2005). Furthermore, in tumour-bearing mice, the decrease in gastrocnemius muscle mass was associated with increased muscle levels of E3 ubiquitin-ligases (Hitt et al. 2005). These data suggest that the decrease in skeletal muscle weight is secondary to an enhanced protein degradation pathway, the ubiquitin-proteasome proteolytic pathway. PEG-sTNFRI administration to arthritic rats increased food intake, but it did not prevent the activation of ubiquitin ligase gene expression. These results suggest that $M u R F-1$ and $M A F b x$ gene expression in the skeletal muscle are independent of food intake. PEG-sTNFRI administration did not change muscular $M u R F-1$ and $M A F b x$ gene expression or gastrocnemius weight in arthritic rats. However, suppression of TNF by pentoxifylline prevented the inhibition of protein synthesis and stimulation of protein degradation as well as the decrease in epitrochlearis muscle weight during sepsis (Vary et al. 1999). These authors suggest that the effect of pentoxifylline in the regulation of protein turnover during sepsis does not appear to be dependent on food intake (Vary et al. 1999).

IGF-I controls muscle mass by enhancing myofibre hypertrophy and stimulating myogenesis (Musaro et al. 2001). However, it has been reported (Foulstone et al. 2001) that the effects of IGF-I on muscle may depend on the cytokine environment in such a way that in the presence of TNF- $\alpha$, IGF-I induces apoptosis. The increase in IGF-I gene expression in skeletal muscle of arthritic rats does not correlate with the decrease observed in the muscle of lipopolysaccharide (LPS)-treated rats (Lang et al. 2000, Fernández-Celemín et al. 2002) and fasting rats (Dehoux et al. 2004). The increase in $M u R F-1$ and $M A F b x$ gene expression found in the skeletal muscle of arthritic rats (Granado et al. 2005) has also been found in the muscle of LPS-injected rats (Dehoux et al. 2003). Muscle mRNA content of MAFbx was also increased in other catabolic situations, such as fasting and diabetes (Dehoux et al. 2004). Since IGF-I has been reported to inhibit MAFbx expression in the muscles of fasting and diabetic rats (Dehoux et al. 2004), the increase in IGF-I in the muscle of arthritic rats should be followed by a decrease in muscular $M u R F-1$ and $M A F b x$ gene expression. Since this is not the case, there is a possibility that arthritic muscles have become resistant to IGF-I, as has been observed in experimental models of sepsis (Fang et al. 2000) and chronic renal failure (Ding et al. 1996). This effect can be exerted by muscular TNF- $\alpha$, since this cytokine acts on muscle cells inducing a state of IGF-I receptor resistance (Broussard et al. 2003). Moreover, anti-TNF therapy improves glucocorticoid-induced IGF-I resistance in rheumatoid arthritis (Sarzi-Puttini et al. 2006).

On the other hand, muscular IGFBP-5 could also contribute to the loss of the beneficial IGF-I effect, since this protein can inhibit or enhance IGF-I activity (Schneider et al. 2002). The widespread growth retardation demonstrated by transgenic mice that overexpress IGFBP- 5 suggests that its predominant effect is inhibitory (Salih et al. 2004). In arthritic rats, we found an increase in muscular IGFBP-5 gene expression, which has been previously reported in muscular atrophy (Awede et al. 1999) and in chondrocytes isolated from osteoarthritic cartilage (Olney et al. 1996). The increase in 
IGFBP-5 in arthritic rats is probably not secondary to the increase in muscular IGF-I, since it has been recently observed in transgenic mice that overexpress IGF-I in muscle that IGFBP-5 mRNA expression was not affected (Musaro et al. 2001, Oliver et al. 2005). However, the increase in IGFBP-5 in arthritic rats could be secondary to the increase in TNF- $\alpha$ release, since TNF- $\alpha$ can stimulate IGFBP-5 in articular chondrocytes (Sunic et al. 1998). Moreover, PEG-sTNFRI administration did not modify $T N F-\alpha$ gene expression in gastrocnemius muscle as it did with the gene expression of IGFBP-5 in this muscle. These results suggest that the lack of effect of PEG-sTNFRI administration on muscular IGF-I gene expression could be due to the lack of effect of PEG-sTNFRI on muscular TNF- $\alpha$ and IGFBP-5.

In accordance with our results, the same dose of PEG-sTNFRI did not modify gastrocnemius IGF-I gene expression in rats with sepsis (Yumet et al. 2002) and in burned rats (Lang et al. 2002). This effect seems to be specific for muscular TNF, since the inhibition of TNF production by PEG-sTNFRI administration was able to attenuate the decrease in hepatic IGF-I mRNA in arthritic (Granado et al. 2006) and septic rats (Yumet et al. 2002). In addition, it was also able to attenuate the increase in hepatic IGF-I mRNA in burned rats (Lang et al. 2002).

The lack of effect of PEG-sTNFRI therapy on TNF- $\alpha$ mRNA in the skeletal muscle of arthritic rats is in agreement with the results observed on TNF- $\alpha$ mRNA in the synovium and in the inguinal lymph nodes after the administration of $10 \mathrm{mg} / \mathrm{kg}$ PEG-sTNFRI in adjuvant arthritis (Bush et al. 2002). In this study, PEG-sTNFRI therapy attenuated the illness, but it did not modify mRNA expression of synovial TNF.

Inhibition of $\mathrm{TNF}-\alpha$ synthesis by xanthine derivatives prevents muscle protein breakdown in septic rats (Vary et al. 1999) and prevents cancer and sepsis-induced increase in muscular ubiquitin gene expression (Combaret et al. 2002). The discrepancy between these findings and our results might be due to the fact that xanthine derivatives inhibit TNF- $\alpha$ synthesis, thus decreasing local and circulating TNF; but in our study, PEG-sTNFRI administration only prevents the effect of circulating TNF. However, other authors have found that inhibiting TNF action by anti-TNF antibodies also reverted the increased muscle ubiquitin gene expression in tumourbearing rats (Llovera et al. 1996). The differences in results could be explained by the fact that in tumour-bearing rats there is a substantial decrease in skeletal muscle TNF- $\alpha$ gene expression (Figueras et al. 2005), while in our study we found an increase in muscular $T N F-\alpha$ gene expression.

Although PEG-sTNFRI was effective as an antiinflammatory agent, improving paw volume and arthritis index scores (Granado et al. 2006) as well as increasing body weight gain, it was not able to block the increase in the gene expression of TNF- $\alpha$ in the muscle of arthritic rats. It has been postulated that TNF- $\alpha$ exerts its catabolic effects in skeletal muscle in a paracrine/autocrine manner
(Fernández-Celemín et al. 2002). Therefore, the gene expression of E3 ubiquitin ligases MuRF-1 and MAFbx in the muscle of arthritic rats was not changed after PEG-sTNFRI administration probably as a consequence of the lack of effect of this protein complex on muscular TNF- $\alpha$.

In conclusion, the administration of PEG-sTNFRI to arthritic rats does not modify the weight of gastrocnemius muscle and muscular $M u R F 1$ and $M A F b x$ gene expression, although it increases body weight and fat mass.

\section{Acknowledgements}

The authors are indebted to A Carmona and MA Ramirez for technical assistance and to $\mathrm{C}$ Bickart for the English correction of the manuscript. PEG-sTNFRI was a kind gift from Amgen Inc (Thousand Oaks, CA, USA).

\section{Funding}

This work was supported by Programa Nacional de Promoción General del Conocimiento, Plan Nacional de Investigación Científica, from the Ministerio de Educación y Ciencia (BFI-2003-02149) and a Fellowship from the Ministerio de Educación y Ciencia to M Granado (FPU, AP2003-2564) and T Priego (FPU, AP2003-2564). The authors declare that there is no conflict of interest that would prejudice the impartiality of this scientific work.

\section{References}

Awede B, Thissen J, Gailly P \& Lebacq J 1999 Regulation of IGF-I, IGFBP-4 and IGFBP-5 gene expression by loading in mouse skeletal muscle. FEBS Letters 461 263-267.

Bar T, Stahlberg A, Muszta A \& Kubista M 2003 Kinetic outlier detection (KOD) in real-time PCR. Nucleic Acids Research 31 e105.

Bodine SC, Latres E, Baumhueter S, Lai VK, Nunez L, Clarke BA, Poueymirou WT, Panaro FJ, Na E, Dharmarajan K et al. 2001 Identification of ubiquitin ligases required for skeletal muscle atrophy. Science 294 1704-1708.

Broussard SR, McCusker RH, Novakofski JE, Strle K, Shen WH, Johnson RW, Freund GG, Dantzer R \& Kelley KW 2003 Cytokine-hormone interactions: tumor necrosis factor $\alpha$ impairs biologic activity and downstream activation signals of the insulin-like growth factor I receptor in myoblasts. Endocrinology 144 2988-2996.

Bush KA, Walker JS, Frazier J \& Kirkham BW 2002 Effects of a PEGylated soluble TNF receptor type 1 (PEG sTNF-RI) on cytokine expression in adjuvant arthritis. Scandinavian Journal of Rheumatology 31 198-204.

Chrysis D \& Underwood LE 1999 Regulation of components of the ubiquitin system by insulin-like growth factor I and growth hormone in skeletal muscle of rats made catabolic with dexamethasone. Endocrinology 140 5635-5641. 
Combaret L, Tilignac T, Claustre A, Voisin L, Taillandier D, Obled C, Tanaka K \& Attaix D 2002 Torbafylline (HWA 448) inhibits enhanced skeletal muscle ubiquitin-proteasome-dependent proteolysis in cancer and septic rats. Biochemical Journal 361 185-192.

Cooney R, Kimball SR, Eckman R, Maish G, III, Shumate M \& Vary TC 1999 TNF-binding protein ameliorates inhibition of skeletal muscle protein synthesis during sepsis. American Journal of Physiology 276 E611-E619.

Costelli P, Carbo N, Tessitore L, Bagby GJ, López-Soriano FJ, Argiles JM \& Baccino FM 1993 Tumor necrosis factor-alpha mediates changes in tissue protein turnover in a rat cancer cachexia model. Journal of Clinical Investigation 92 2783-2789.

Dehoux MJM, van Beneden RP, Fernández-Celemín L, Lause PL \& Thissen JPM 2003 Induction of MafBx and Murf ubiquitin ligase mRNAs in rat skeletal muscle after LPS injection. FEBS Letters 544 214-217.

Dehoux M, Van Beneden R, Pasko N, Lause P, Verniers J, Underwood L, Ketelslegers JM \& Thissen JP 2004 Role of the insulin-like growth factor I decline in the induction of atrogin-1/MAFbx during fasting and diabetes. Endocrinology 145 4806-4812.

Ding H, Gao XL, Hirschberg R, Vadgana JV \& Kopple JD 1996 Impaired actions of insulin-like growth factor I on protein synthesis and degradation in skeletal muscle of rats with chronic renal failure. Evidence for a postreceptor defect. Journal of Clinical Investigation 97 1064-1075.

Fang CH, Li BG, Sun X \& Hasselgren PO 2000 Insulin-like growth factor I reduces ubiquitin and ubiquitin-conjugating enzyme gene expression but does not inhibit muscle proteolysis in septic rats. Endocrinology 141 2743-2751.

Fernández-Celemín L, Pasko N, Blomart V \& Thissen JP 2002 Inhibition of muscle insulin-like growth factor I expression by tumor necrosis factor- $\alpha$. American Journal of Physiology 283 E1279-E1290.

Figueras M, Busquets S, Carbo N, Almendro V, Argiles JM \& Lopez-Soriano FJ 2005 Cancer cachexia results in an increase in TNF-alpha receptor gene expression in both skeletal muscle and adipose tissue. International Journal of Oncology 27 855-860.

Foulstone EJ, Meadows KA, Holly JM \& Stewart CE 2001 Insulin-like growth factors (IGF-I and IGF-II) inhibit C2 skeletal myoblast differentiation and enhance TNF alpha-induced apoptosis. Journal of Cellular Physiology 189 207-215.

Gomes MD, Lecker SH, Jagoe RT, Navon A \& Goldberg AL 2001 Atrogin-1, a muscle-specific F-box protein highly expressed during muscle atrophy. PNAS 98 14440-14445.

Granado M, Priego T, Martín AI, Villanúa MA \& López-Calderón A 2005 The ghrelin receptor agonist GHRP-2, prevents artritis-induced increase in E3 ubiquitin-ligating encimes $M u R F 1$ and $M A F b x$ gene expression in skeletal muscle. American Journal of Physiology 289 E1007-E1014.

Granado M, Priego T, Martín AI, Vara E, López-Calderón A \& Villanúa MA 2006 Anti-tumor necrosis factor agent PEG-sTNFRI improves the growth hormone/insulin-like growth factor-I system in adjuvant-induced arthritic rats. European Journal of Pharmacology 536 204-210.

Hamada K, Vannier E, Smith DE, Abad LW \& Roubenoff R 2000 Inflammatory cachexia induces sarcoactive cytokine gene expression in a rat model of adjuvant arthritis. Journal of the Federation for the American Society for Experimental Biology 14 A572 (Abstract).

Hasselgren PO, James JH, Benson DW, Hall-Angeras M, Angeras U, Hiyama DT, Lis S \& Fischer JE 1989 Total and myofibrillar protein breakdown in different types of rat skeletal muscle: effects of sepsis and regulation by insulin. Metabolism 38 634-640.

Hershko A, Ciechanover A \& Varshavsky A 2000 The ubiquitin system. Nature Medicine 6 1073-1081.

Hitt A, Graves E \& McCarthy DO 2005 Indomethacin preserves muscle mass and reduces levels of $\mathrm{E} 3$ ligases and TNF receptor type 1 in the gastrocnemius muscle of tumor-bearing mice. Research in Nursing $\&$ Health 28 56-66.

Hoshino E, Pichard C, Greenwood CE, Kuo GC, Cameron RG, Kurian R, Kearns JP, Allard JP \& Jeejeebhoy KN 1991 Body composition and metabolic rate in rat during a continuous infusion of cachectin. American Journal of Physiology 260 E27-E36.
Ibáñez de Cáceres I, Villanúa M, Soto L, Martín AI \& López-Calderón A 2000 Insulin-like growth factor (IGF-I) and IGF-binding proteins in rats with adjuvant-induced arthritis given recombinant human growth hormone. Journal of Endocrinology 165 537-544.

Lang CH, Frost RA, Jefferson LS, Kimball SR \& Vary TC 2000 Endotoxininduced decrease in muscle protein synthesis is associated with changes in dIF2B, eIF4E, and IGF-I. American Journal of Physiology 278 E1133-E1144.

Lang CH, Nystrom GJ \& Frost RA 2002 Burn-induced changes in IGF-I and IGF-binding proteins are partially glucocorticoid dependent. American Journal of Physiology 282 R207-R215.

Lecker SH, Jagoe RT, Gilbert A, Gomes M, Baracos V, Bailey J, Price SR, Mitch WE \& Goldberg AL 2004 Multiple types of skeletal muscle atrophy involve a common program of changes in gene expression. FASEB Journal 18 39-51.

Livak KJ \& Schmittgen TD 2001 Analysis of relative gene expression data using real-time quantitative PCR and the 2[-Delta Delta $\mathrm{C}(\mathrm{T})]$ method. Methods 25 402-408.

Llovera M, Carbo N, García-Martínez C, Costelli P, Tessitore L, Baccino FM, Agell N, Bagby GJ, Lopez-Soriano F \& Argiles JM 1996 Anti-TNF treatment reverts increased muscle ubiquitin gene expression in tumourbearing rats. Biochemical and Biophysical Research Communications 221 653-655.

Llovera M, García-Martinez C, Agell N, Lopez-Soriano FJ \& Argiles JM 1997 TNF can directly induce the expression of ubiquitin-dependent proteolytic system in rat soleus muscles. Biochemical and Biophysical Research Communications 230 238-241.

Llovera M, García-Martinez C, López-Soriano J, Carbó N, Agell N, LopezSoriano FJ \& Argiles JM 1998 Role of TNF receptor-1 in protein turnover during cancer cachexia using gene knockout mice. Molecular and Cellular Endocrinology 142 183-189.

Mitch WE \& Goldberg AL 1996 Mechanisms of muscle wasting: the role of the ubiquitin-proteasome pathway. New England Journal of Medicine 335 1897-1905

Musaro A, McCullagh K, Paul A, Houghton L, Dobrowolny G, Molinaro M, Barton ER, Sweeney HL \& Rosenthal N 2001 Localized IGF-1 transgene expression sustains hypertrophy and regeneration in senescent skeletal muscle. Nature Genetics 27 195-200.

Oliver WT, Rosenberger J, Lopez R, Gomez A, Cummings KK \& Fiorotto ML 2005 The local expression and abundance of insulin-like growth factor (IGF) binding proteins in skeletal muscle are regulated by age and gender but not local IGF-I in vivo. Endocrinology 146 5455-5462.

Olney RC, Tsuchiya K, Wilson DM, Mohtai M, Maloney WJ, Schurman DJ \& Smith RL 1996 Chondrocytes from osteoarthritic cartilage have increased expression of insulin-like growth factor I (IGF-I) and IGFbinding protein-3 (IGFBP-3) and -5, but not IGF-II or IGFBP-4. Clinical Endocrinology and Metabolism 81 1096-1113.

Roubenoff R, Freeman LM, Smith DE, Abad LW, Dinarello CA \& Kehayias JJ 1997 Adjuvant arthritis as a model of inflammatory cachexia. Arthritis and Rheumatism 40 534-539.

Salih DA, Tripathi G, Holding C, Szestak TA, Gonzalez MI, Carter EJ, Cobb LJ, Eisemann JE \& Pell JM 2004 Insulin-like growth factor-binding protein 5 (Igfbp5) comprises survival, growth, muscle development, and fertility in mice. PNAS 101 4314-4319.

Sarzi-Puttini P, Atzeni F, Scholmerich J, Cutolo M \& Straub RH 2006 AntiTNF antibody therapy improves glucocorticoid-induced insulin-like growth factor-1 (IGF-1) resistance without influencing myoglobin and IGF-1 binding proteins 1 and 3. Annals of the Rheumatic Diseases $\mathbf{6 5}$ 301-305.

Schneider MR, Wolf E, Hoeflich A \& Lahm H 2002 IGF-binding protein-5: flexible player in the IGF system and effector on its own. Journal of Endocrinology 172 423-440.

Solorzano CC, Kaibara A, Hess PJ, Edwards PD, Ksontini R, Abouhamze A, McDaniel S, Frazier J, Trujillo D, Kieft G et al. 1998 Pharmacokinetics, immunogenicity, and efficacy of dimeric TNFR binding proteins in healthy and bacteremic baboon. Journal of Applied Physiology $\mathbf{8 4}$ $1119-1130$. 
Sunic D, McNeil JD, Rayner TE, Andress DL \& Belford DA 1998 Regulation of insulin-like growth factor-binding protein- 5 by insulin-like growth factor I and interleukin- $1 \alpha$ in ovine articular chondrocytes. Endocrinology $1392356-2362$.

Tanaka H, Ueta Y, Yamashita U, Kannan M \& Yamashita H 1996 Biphasic changes in behavioural, endocrine and sympathetic systems in adjuvant artritis in Lewis rats. Brain Research Bulletin 39 33-37.

Tisdale MJ 2000 Protein loss in cancer cachexia. Science 289 2293-2294.

Tracey KJ, Morgello S, Koplin B, Fahey TJ, Fox J, Aledo A, Manogue KR \& Cerami A 1990 Metabolic effects of cachectin/tumor necrosis factor are modified by site of production. Cachectin/tumor necrosis factor-secreting tumor in skeletal muscle induces chronic cachexia, while implantation in brain induces predominantly acute anorexia. Journal of Clinical Investigation 86 2014-2024.
Vary T, Dardevet D, Grizard J, Voisin L, Buffiere C, Denis P, Breuille D \& Obled C 1999 Pentoxifylline improves insulin action limiting skeletal muscle catabolism after infection. Journal of Endocrinology 163 15-24.

Warne JP 2003 Tumor necrosis factor $\alpha$ : a key regulator of adipose tissue mass. Journal of Endocrinology 177 351-355.

Yumet G, Shumate ML, Bryant P, Lin CM, Lang CH \& Cooney RN 2002 Tumor necrosis factor mediates hepatic growth hormone resistance during sepsis. American Journal of Physiology 283 E472-E481.

Received 24 April 2006

Accepted 25 July 2006 